\title{
MEMBANGUN KESADARAN HUKUM PADA MASA PANDEMI COVID-19 MELALUI PENGEMBANGAN RENCANA PELAKSANAAN PEMBELAJARAN
}

\author{
Rahmanu Wijaya, Warsono, Nanik Setyowati, dan Maya Mustika Kartika Sari \\ Fakultas Ilmu Sosial dan Hukum, Universitas Negeri Surabaya \\ rahmanuwijaya@unesa.ac.id
}

\begin{abstract}
The President of the Republic of Indonesia has established the status of a health emergency in the Presidential Decree 11 of 2020, as well as stated in Presidential Decree 12 of 2020 that non-natural disasters caused by COVID-19 as a national disaster. The consequence is the birth of the role of the government through legal instruments and actions to control the community, so it is important to build legal awareness. In this case the teacher has the authority to form a Learning Implementation Plan (RPP) applied to students, then the legal research conducted aims to know the authority of teachers mapel Pancasila Education and Citizenship (PPKn) junior high school level (SMP) in drafting RPP to build legal awareness regarding the condition of the Covid-19 pandemic. Using the Statute Approach method, which is based on the legislation on the authority of teachers and related to the status of health emergencies and non-natural disasters. The results showed that PPKN teachers have the authority to develop RPP that builds legal awareness for students, especially with regard to the control exercised by the government during the pandemic.
\end{abstract}

Keywords: PPKn Teacher; RPP; Legal Awareness

\section{Abstrak}

Presiden RI telah menetapkan status kedaruratan kesehatan dalam Kepres 11 Tahun 2020, sekaligus menyatakan dalam Kepres 12 Tahun 2020 bahwa bencana non alam yang diakibatkan COVID-19 sebagai bencana nasional. Konsekwensi yang ditimbulkan adalah lahirnya peran pemerintah melalui instrumen hukum serta perbuatan guna mengendalikan masyarakat, sehingga penting dibangun kesadaran hukum. Dalam hal ini guru memiliki kewenangan untuk membentuk Rencana Pelaksanaan Pembelajaran (RPP) yang diterapkan kepada siswa, maka penelitian hukum yang dilakukan bertujuan untuk mengetahui kewenangan guru mapel Pendidikan Pancasila dan Kewarganegaraan (PPKn) tingkat Sekolah Menengah Pertama (SMP) dalam menyusun RPP guna membangun kesadaran hukum berkenaan kondisi pandemi Covid - 19. Menggunakan metode Statute Approach, yaitu dengan mendasarkan pada peraturan perundangan mengenai kewenangan guru serta yang terkait dengan status kedaruratan kesehatan dan bencana non alam. Hasil penelitian menunjukkan bahwa guru PPKn memiliki kewenangan untuk mengembangkan RPP yang membangun kesadaran hukum bagi siswa, khususnya berkaitan dengan pengendalian yang dilakukan oleh pemerintah pada masa pandemi.

\section{Kata kunci : Guru PPKn; RPP; Kesadaran Hukum}




\section{A. Pendahuluan}

Pembukaan UUD NRI Tahun 1945 telah tegas menyatakan bahwa tujuan dibentuknya pemerintah negara Indonesia diantaranya adalah untuk memberikan perlindungan kepada bangsa dan karenanya seluruh rakyat Indonesia, peran yang sangat luas ini kemudian pelaksanaannya dibingkai dalam bentuk instrumen hukum dan perbuatan-perbuatan pemerintahan. Hal ini terlihat adanya relasi antara negara dengan pemerintah, dimana Logeman dalam Muchsan menyebut negara merupakan kumpulan jabatan-jabatan atau jabatan yang terorganisir. Pada hakekatnya, negara tersebut abstrak. Sementara yang nyata adalah jabatan dalam pemerintahan negara, maka dengan jabatan inilah kemudian dapat diwujudkan suatu tujuan negara. ${ }^{1}$ Sedangkan yang dimaksud dengan pemerintah, Kuntjoro Purbopranoto secara tegas membedakannya menjadi dua yaitu: - Pemerintah secara luas; dan - Pemerintah secara sempit. Luas atau sempitnya tersebut sebenarnya berkaitan dengan tugas dan wujud badannya, dalam arti dikatakan luas jika tugas yang dimaksud melingkupi segala sesuatu yang berkenaan dengan tujuan negara dan berwujud seluruh badan secara tidak terbatas. Pendek kata, sepanjang badan atau dalam perspektif hukum administrasi adalah pejabat tersebut melaksanakan tujuan negara maka dia dikualifikasikan sebagai pemerintah dalam arti luas. Sementara dalam arti sempit, pemerintah hanya berwujud pada badan atau pejabat yang menjalankan tugas pemerintahan. ${ }^{2}$ Sederhananya merujuk

1 Muchsan, (1981), Beberapa Catatan tentang Hukum Administrasi Negara dan Peradilan Admnistrasi di Indonesia, Yogyakarta: Liberty, hlm. 9-10

${ }^{2}$ Muchsan, (2007), Sistem Pengawasan Terhadap Perbuatan Aparat Pemerintah dan Peradilan Tata Usaha Negara di Indonesia, Yogyakarta: Liberty, hlm. 14 pada konstitusi di Indonesia, bahwa cabang kekuasaan negara secara tegas terbagi dalam tiga, yaitu: legislatif, eksekutif, dan yudikatif. Cabang kekuasaan eksekutif ini disebut secara tegas dalam UUD sebagai kekuasaan pemerintahan, maka siapapun juga badan yang terafiliasi didalamnya berikut juga fungsinya adalah sejalan dengan fungsi pemerintahan maka dia disebut sebagai pemerintah dalam arti yang sempit. Konkritnya pemerintah Indonesia merupakan seluruh aktor yang terlibat guna memberikan perlindungan kepada bangsa dan karenanya seluruh rakyat Indonesia. Lebih lanjut lagi pengelolaannya berdasarkan ketentuan Pasal 18 Konstitusi di Indonesia, terdiri dari pemerintah pusat dan pemerintah daerah.

Berbicara mengenai pemberian perlindungan kepada bangsa dan karenanya seluruh rakyat Indonesia, Undang-undang RI No. 24 Tahun 2007 telah menggaris ketentuan perlindungan dari bencana. Dimana makna bencana sebagaimana dalam Pasal 1 angka 1 UU tersebut adalah "segala sesuatu yang bersifat ancaman, dimana dengan adanya ancaman tersebut akan mengganggu masyarakat" Sedangkan berdasarkan ketentuan yang lain dalam UU tersebut, klasifikasi bencana terdiri dari : -Bencana alam; dan -Bencana non alam. Suatu bencana disebut bencana dari yaitu yang melatar belakangi adalah murni alam, sedangkan bencana non alam sebagaimana dalam angka berikutnya UU tersebut adalah bencana yang diakibatkan oleh faktor non alam. Kondisi sebagaimana dimaksud mensyaratkan adanya penetapan yang dikeluarkan oleh pemerintah, dalam hal ini adalah status keadaan darurat bencana. Poinnya setelah ditetapkan status keadaan darurat bencana, maka yang berikutnya lahir peran pemerintah dalam hal mitigasi, tanggap darurat, rehabilitasi, rekonstruksi, hingga pemulihan. Prinsipnya pemerintah baik itu pusat maupun daerah terlihat sangat berperan dalam aktivitas ini, 
hal ini diwujudkan melalui instrumen-instrumen hukum serta perbuatan pemerintah.

Sejalan dengan kondisi pandemi covid 19 di Indonesia, Pemerintah RI melalui Presiden telah menetapkan status kedaruratan kesehatan dalam Kepres 11 Tahun 2020, sekaligus menyatakan dalam Kepres 12 Tahun 2020 bahwa bencana non alam yang diakibatkan COVID-19 tersebut sebagai bencana nasional. Segala aktivitas yang berkaitan dengan misi penanggulangan bencana covid 19 tersebut didukung dengan prinsip pengelolaan keuangan negara yang berpedoman pada UU, termasuk diantaranya berkenaan dengan bagaimana upaya disiplin serta menegakkan hukum yang berkait protokol kesehatan yaitu melalui pernyataan atau perintah Presiden.

Beragam instrumen hukum serta aktivitas tersebut perlu ditunjang dengan kesadaran hukum masyarakat, yaitu sederhananya adalah kondisi yang benar-benar paham serta kritis terhadap hukum. Dalam hal ini masyarakat tentunya mesti mengetahui dengan cermat untuk apa hukum dibuat termasuk yang berwujud perbuatan pemerintah, sekaligus taat terhadapnya. Bukan taat yang tanpa alasan, melainkan taat yang benar-benar dilator belakangi kesadaran tinggi. Paparan shahih mengenai kesadaran hukum memang belum cukup ditemukan, tetapi sekedar sebagai pedoman dapat digunakan pandangan Ewick dan Silbey yang menyebut kesadaran terhadap hukum adalah berkenaan dengan cara pandang seseorang terhadap serangkaian instrumen-instrumen hukum. ${ }^{3}$ Bukan tanpa alasan masyarakat "dipaksa" untuk sadar hukum, namun memang sejalan dengan latar belakang hukum yang lahir atau dalam bahasa Sudikno Mertokusumo sebagai "Raison d'etre" guna

\footnotetext{
${ }^{3}$ Achmad Ali, (2002), Keterpurukan Hukum di Indonesia, Jakarta: Ghalia Indonesia, hlm. 11-12

${ }^{4}$ Sudikno Mertokusumo, (2003), Bunga Rampai Ilmu Hukum, Jogjakarta: Liberty, hlm. 131
}

mencegah konflik atau kondisi yang tidak teratur. Konkritnya ketika sedang terjadi keadaan bencana pandemi Covid-19 ini seluruh masyarakat harus taat, dan berada dalam "satu garis komando" dengan pemerintah melalui hukum.

Nilai kesadaran hukum sebagaimana disebutkan Soerjono Soekanto, pada prinsipnya dibangun melalui pendidikan baik formal maupun non formal. ${ }^{5}$ Pendidikan formal yang dimaksud meliputi usia TK, SD, SMP, SMA, hingga Perguruan Tinggi, tingkat kesadaran hukum yang dibangun tentunya levelnya berbeda-beda. Dalam penyelenggaraan pendidikan tersebut, guru memegang perananan yang sangat vital. Serta dalam pelaksanaanya, guru mengorganisir kegiatan pembelajaran melalui suatu rencana pelaksanaan pembelajaran.

Pemerintah dalam rangka kondisi pandemi Covid-19 melalui perbuatan-perbuatannya yang didukung instrumen hukum pada akhirnya harus didukung sepenuhnya oleh masyarakat, hal ini merupakan esensi dari kesadaran hukum. Tidak semata-mata "menghamba", namun taat yang didasari kondisi sangat memahami tipikal serta alasan hukum tersebut dibentuk. Dalam rangka membangun kesadaran demikian, pendidikan memegang peranan penting. Dalam pendidikan peran tersebut dimaterialkan oleh guru, yang aktivitasnya dipandu oleh Rencana Pelaksanaan Pembelajaran. Maka sejalan dengan kebutuhan-kebutuhan tersebut, masalah akan dirumuskan melalui bentuk kalimat : (1) Apakah yang menjadi pokok-pokok kesadaran hukum pada masa pandemi Covid-19 ? (2) Apakah guru PPKn SMP memiliki kewenangan menyusun Rencana Pelaksanaan Pembelajaran (RPP) dengan substansi kesadaran hukum tersebut ?.

\footnotetext{
5 Soerjono Soekanto, (2012), Faktor-faktor yang Mempengaruhi Penegakan Hukum, Jakarta: Raja Grafindo Persada, cet.11, hlm. 274
} 


\section{B. Metode Penelitian}

Metode pendekatan peraturan perundangundangan sebagai basis aktivitas yaitu dengan merujuk pada instrumen-instrumen primer berupa UUD NRI Tahun 1945, UU terkait termasuk segala sesuatu yang secara formal termasuk sebagai regells. Sebagai pendukung atau pelengkap, digunakanlah bahan lain yang secara keseluruhan mendukung bahan hukum primer, keseluruhan bahan hukum dikelompokkan dan dikaji secara sistimatis serta dibandingkan dengan dengan saling terkait hingga kemudian dilakukan pengkajian norma.

\section{Hasil dan Pembahasan}

Kondisi pandemi Covid-19 di Indonesia sebagaimana telah ditetapkan oleh Presiden RI telah berdampak bagi seluruh umat manusia, baik masyarakat luas maupun organorgan atau alat kelengkapan negara yang dikualifikasikan sebagai pemerintah. Siapapun juga orangnya dapat terdampak, baik berupa kesehatan, ekonomi, psikis, dan lainnya. Maka dalam hal ini ide gotong royong yang digaungkan pemerintah tepat didukung, dalam arti seluruh elemen manusia Indonesia harus bergandengan tangan memerangi bencana nasional ini. Penggeraknya adalah pemerintah, hal ini karena memang perannya sebagai "chief". Berjalannya ide gotong royong tersebut dibalut oleh instrumen hukum, yang pada akhirnya mesti dipahami dan ditaati oleh segenap lapisan masyarakat termasuk bahkan anak usia sekolah. Kesadaran hukum perlu dibangun, dalam kaitan tersebut guru PPKn SMP sebagai salah seorang pelaku yang sangat berperan dalam dunia pendidikan formal merupakan kekuatan strategis untuk menyemai kesadaran hukum.

\section{Pokok-pokok Kesadaran Hukum yang Berhubungan dengan Pandemi Covid - 19}

Kondisi pandemi tahun 2020 benarbenar menyebabkan dampak yang sangat menyeluruh bagi kehidupan masyarakat, serta bahkan bernegara di Indonesia. Kebersamaan secara jasmani sebagai budaya masyarakat, secara drastis langsung berubah menjadi berjarak. Dalam konteks kehidupan bernegara, secara cepat pula Pemerintah menurut catatan Darmin Tuwu telah mengeluarkan kebijakankebijakan berikut : - Kebijakan tidak keluar dari rumah; - Kebijakan yang berkaitan dengan membatasi berhubungan; - Kebijakan berkenaan dengan jarak; - Kebijakan menggunakan masker dan lain-lannya sebagai sarana perlindungan; - Kebijakan selalu mencuci tangan dan sarana kebersihan; - Kebijakan mengubah pola kerja dan pendidikan; Kebijakan yang berkaitan dengan aktivitas kerumunan; - Kebijakan pembatasan sosial berskala besar; - Kebijakan normal baru. ${ }^{6}$ Memahami makna kata "kebijakan" sebagaimana catatan Tuwu tersebut, dapat berpedoman pada pandangannya I Gde Pantja Astawa yang memposisikan kebijakan tersebut sebagai salah satu peraturan negara. Lebih lanjut dinyatakan bahwa peraturan negara (staatsregelings) dapat dibagi dalam tiga kelompok, yaitu: - Peraturan perundangundangan (wettelijk regeling); - Peraturan kebijakan (beleidregels); - Penetapan (Beschiking). ${ }^{7}$ Spesifik mengenai kebijakan adakalanya dinyatakan dalam bahasa yang sederhana adalah bersumber, sehingga pemerintah yang berwujud jabatan-jabatan publik atau badan tata usaha negara dalam memainkan kebijakan

${ }^{6}$ Darmin Tuwu (May - July 2020), Kebijakan Pemerintah dalam Penanganan Pandemi Covid - 19, Journal Publicuho, Vol. 3, Number 2, hlm. 273

${ }^{7}$ I Gde Pantja Astawa. (2008), Dinamika Hukum dan Ilmu Perundang-undangan di Indonesia, Bandung: Alumni, hlm. 37 
terdapat sumber yang jelas dan tegas. Adakalanya juga pemerintah dimaksud dalam aktivitas jabatannya membuat suatu kebijakan secara bebas, yaitu berdasarkan kewenangan kebebasan bertindak (freies ermessen). Bicara mengenai wujudnya, kebijakan-kebijakan ini adakalanya mengikuti kaidah penulisan sebagaimana peraturan perundang-undangan namun adakalanya berlainan dengan kaidah dalam penulisan naskah peraturan perundangundangan. Maka adakalanya masyarakat dapat dengan mudah membedakan yang mana kebijakan dan yang mana peraturan perundang-undangan, namun adakalanya yang lain adalah sangat susah untuk membedakan antara kebijakan dengan peraturan perundangundangan dikarenakan bentuknya sama persis. Berbicara mengenai bentuk ini, sebagaimana A. Hamid S Attamimi, menyebut adakalanya tertulis: - Terdapat bagian pembukaan yang lengkap dengan konsiderans; - Terdapat bagian-bagian batang tubuh, dimana didalamnya terdapat Pasal per Pasal; - Terdapat bagian penutup. Sangat persis, segala sesuatunya sama dengan peratuiran perundang-undangan. Sementara wujud kebijakan yang teknis penyusunannya berbeda dari peraturan perundang-undangan, yang dimaksud adalah lebih ringkas. Konkritnya berwujud nota dinas, surat edaran, petunjuk pelaksanaan, petunjuk teknis, pengumuman serta lainnya. ${ }^{8}$ Prinsipnya, bentuk-bentuk tersebut adakalanya sama secara formal tetapi yang dimaksud dengan kebijakan tersebut memiliki dimensi yang berbeda dengan peraturan perundang-undangan. Lebih berbeda lagi dengan penetapan atau dalam istilah lain disebut sebagai keputusan atau ketetapan, dimana menurut Philipus M. Hadjon terletak pada karakteristik yang

${ }^{8}$ A. Hamid S Attamimi. (1985), Materi Muatan Peraturan Perundang-undangan, Jurnal Hukum \& Pembangunan, Vol. 15, hlm. 57-58 individual dan konkrit. ${ }^{9}$ Meskipun ketiganya berbeda, namun sama-sama sebagai peraturan negara yang oleh karenanya merupakan hukum. Hal ini senada dengan pandangan Sudikno Mertokusumo tentang hukum, yaitu keseluruhan peraturan tingkah laku bagi setiap orang yang diadakan oleh badan-badan resmi atau pemerintah. ${ }^{10}$

Sementara Peraturan perundangundangan sebagai salah satu peraturan negara, wujudnya secara tegas dapat digaris dalam ketentuan UU Pembentukan Peraturan Perundangan terdiri dari enam jenis peraturan perundangan. Dimana kesemuanya itu senantiasa berpedoman pada Pancasila sebagai dasar negara, maknanya yang dimaksud dengan peraturan perundang-undangan jenisnya telah jelas dan tegas. Diluar yang ditentukan dalam UU Pembentukan Perundangan, maka jelas bukan sebagai sebuah peraturan perundang-undangan. Prinsipnya peraturan perundang-undangan tersebut selalu mengikat publik, dan karenanya publik secara fiksi dianggap selalu tahu akan suatu peraturan perundang-undangan. Peraturan perundangundangan ini di Indonesia merupakan salah satu sumber hukum, saling sinergi dengan sumber-sumber hukum yang lain. Diluar peraturan perundangan, yang dinyatakan sebagai sumber hukum adalah putusan hakim. Berbeda dimensinya dengan peraturan perundangan, dalm arti peraturan perundangan tersebut memiliki daya jangkau publik. Dapat menyasar kepada setiap subyek, berkebalikan dengan putusan yang hanya tertuju pada subyek tertentu yaitu yang namanya disebutkan dalam suatu putusan. Konkritnya bicara siapa yang harus taat, jika hukum berwujud

9 Philipus M. Hadjon, dkk. (2019), Pengantar Hukum Administrasi Indonesia, Yogyakarta: UGM Press, hlm. 151

10 Sudikno Mertokusumo. (1999), Mengenal Hukum (Suatu Pengantar), Yogyakarta: Liberty, hlm. 5 
peraturan perundangan maka seluruhnya harus taat sedangkan jika wujudnya berupa putusan maka hanya subyek tertentu yang harus taat. Meskipun demikian terdapat putusan yang memiliki sifat erga omnes, yaitu dihasilkan oleh lembaga peradilan bidang tata usaha negara serta mahkamah konstitusi. Bahwa putusan yang dihasilkan oleh dua lembaga ini memiliki daya ikat publik, hal ini layaknya sebuah peraturan perundangan. Diluar iu juga masih terdapat sumber hukum lainnya, prinsipnya segala yang dimaksud adalah dikualifikasikan sebagai hukum dan beberapa diantaranya mesti ditaati oleh semua subyek.

Perihal alasan ditaatinya hukum oleh subyek ini harus dicermati ikhwal yang menjadi latar belakang hukum ada, yaitu mencegah adanya benturan kepentingan dalam arti lain adalah mengkonstruksikan ketertiban dalam suatu masyarakat. Hal ini logis, karena dalam struktur bagaimanapun juga masyarakat memiliki potensi konflik yang tentu akan berpengaruh dalam kehidupannya. Konflik tersebut harus dicegah atau ketika terjadi, maka harus ada perangkat atau sarana untuk menyelesaikannya. Perangkat yang dimaksud adalah norma, dimana keberadaannya di masyarakat berjalan saling beriringan norma-norma. Berkenaan dengan norma yang hidup di masyarakat, salah satunya adalah hukum. Maka keberadaan hukum sesungguhnya memiliki pengertian atau alasan yang sama dengan norma-norma lain, yaitu hendak mengkonstruksikan agar masyarakat atau secara umum seluruh subyek tertib. Salah satunya berwujud peraturan perundangan, hal ini tentu adanya peraturan perundangan bertujuan menciptakan ketertiban. Makna sederhana dari ketertiban tidak berarti seragam, atau harus diam. Melainkan wujud ketertiban adalah berperilaku sesuai dengan hukum, tidak semata-mata karena takut melainkan karena paham pentingnya serta tepat atau tidaknya keberadaan suatu hukum.
Dalam kaitannya dengan penanggulangan bencana berwujud pandemi Covid-19, ketentuan Pasal 5 UU RI No. 24 Tahun 2007 telah tegas menyebut penanggulangannya menjadi beban negara. Dalam hal ini pusat dan daerah secara bersinergi memiliki kewenangan masing-masing untuk menanggulangi keadaan bencana, hal ini sehingga terlihat peranannya masing-masing. dimana peranan pusat meliputi: - mengurangi risiko dan melakukan pembangunan-pembangunan; - memberikan perlindungan; - mewujudkan hak serta kebutuhan secara adil; - memulihkan akibat bencana; - menetapkan anggaran-anggaran; mendistribusikan anggaran dimaksud; - memelihara barang-barang; - menetapkan kebijakan menanggulangi keadaan; - menyusun rencana-rencana yang terkait; - menetapkan status; - menggalang kerjasama termasuk dengan badan internasional; - Merumuskan teknologi tepat; - merumuskan sumber daya; dan - mengendalikan sumbangan-sumbangan. Sementara itu peranan daerah dalam aktivitas yang berorientasi pada kegiatan penanggulangan bencana, meliputi: - menjamin masyarakat dan pengungsi di daerah; - melindungi dari segala dampak; - mengurangi resiko, dalam hal ini adalah sinergi dengan pusat; mengalokasikan dana, penganggaran dalam hal ini adalah masuk dalam anggaran daerah; menetapkan kebijakan-kebijakan penanggulangan yang selaras dengan iklim daerah; membuat rencana pembangunan-pembangunan; - melaksanakan kerjasama dengan daerah-daerah lainnya; - mengatur yang berkaitan dengan teknologi; - merumuskan kebijakan penanggulangan; dan - menertibkan penyaluran bantuan dan sejenisnya di daerah. Sehingga segala kebijakan terikat yang berkenaan dengan penanganan dampak Covid-19 baik pada kedudukan pusat maupun kedudukan di daerah tersebut sesungguhnya ialah merujuk pada peraturan perundangan, konkritnya mengenal latar belakang hingga menentukan pengujian terhadapan kebijakan 
yang dilakukan oleh pemerintah maka dapat digunakan peraturan perundangan sebagai dasarnya.

Penekanan berkaitan dengan keberadaan peraturan perundangan tersebut, bahwa peraturan perundangan juga menjadi pijakan bagi pemerintah dalam mengeluarkan kebijakan. Dari sini maka segala sesuatu yang berkenaan dengan kebijakan pemerintah pada masa pandemi ini tidak semata-mata bebas yang sebebasnya, melainkan manakala sumbernya adalah kewenangan yang digaris dalam peraturan perundangan maka sumbernya jelas. Sementara ketika pemerintah sedang menjalankan aksi yang berkaitan dengan aspek kemanfaatan, maka tolok ukurnya adalah patut atau tidak kebijakan tersebut dilakukan

Berjalannya aktivitas termasuk pada akhirnya juga hukum pada masa pandemi Covid-19 tersebut sangat bergantung pada kesadaran hukum masyarakat, yaitu menurut Krabe sebagaimana dikutip Achmad Ali dan Wiwie Heryani adalah keadaan jiwa menyangkut nilai dalam dirinya mengenai hukum yang berlaku atau yang diidealkan ada. ${ }^{11}$ Senada dengan pandangan tersebut, S. Soekanto dalam pandangannya mengenai keadaan tersebut juga menitik beratkan pada persoalan nilai, lebih tegasnya berkenaan dengan nilai adalah merujuk pada fungsi aturan. Hal ini dengan kata lain tidak dalam rangka menilai keadaan, namun pada fungsi. ${ }^{12}$ Dimensi nilai menjadi persoalan yang utama dalam kesadaran hukum, sehingga seseorang yang telah sadar hukum adalah mengenal dengan sungguh-sungguh nilai berkenaan dengan hukum dimaksud. Hal ini sehingga dikatakan bahwa seseorang yang sadar hukum

11 Achmad Ali dan Wiwie Heryani. (2012), Menjelajahi kajian Empiris Terhadap Hukum, Jakarta: Kencana, hlm. 141

${ }^{12}$ Soerjono Soekanto. (2002), Kesadaran Hukum dan Kepatuhan Hukum, Jakarta: Raja Grafindo Persada, hlm. 215 tidak dalam kapasitas mengerti bahkan menghafalkan setiap peraturan perundangan termasuk sumber-sumber hukum lainnya, nemun lebih dari itu adalah memahami esensi setiap peraturan-peraturan hukum dibentuk. Sehingga alasan ditaatinya bukan karena takut terhadap sanksi, namun dikarenakan benarbenar sadar jika aturan hukum tersebut penting untuk mengubah keadaan.

\section{Kebutuhan RPP PPKn Tingkat SMP Tentang Kesadaran Hukum}

Keberadaan RPP dalam sebuah mata pelajaran sebagaimana disampaikan oleh Suyono adalah berkenaan dengan bagaimana mengelola kelas atau suatu aktivitas pembelajaran agar benar-benar sejalan dengan silabus, hal ini menjadi komponen yang wajib ada atau wajib dipenuhi oleh guru. Lebih lanjut diuraikan bahwa rencana tersebut dikembangkan dari kurikulum, yang keberadaannya dapat diketahui atau dapat dikenali dalam silabus. Pada umumnya silabus ini dibuat secara nasional, atau paling tidak terdapat dimensi yang tidak hanya digunakan di sebuah sekolah. Agar silabus tersebut tersampaikan dengan baik, maka peran guru adalah menyusun rencana pembelajaran terlebih dahulu. ${ }^{13}$ Lebih lanjut, E Kosasih menyatakan bahwa unsur-unsur rencana dimaksud berisi: - penamaan; - kompetensikompetensi; - detail atau spesifik lanjutan mengenai kompetensi; - alasan-alasan; ukuran atau parameter; - bahan-bahan; penggunaan waktu; - teknik-teknik; perangkat; - aktivitas. ${ }^{14}$ Komponen-komponen tersebut sedikit mengalami perubahan dalam Permendikbud RI, diantaranya menjadi : nama sekolah; - identitas-identitas; -

13 Suyono. (2015), Implementasi Belajar Dan Pembelajaran, Bandung: PT. Remaja Rosdakarya, hlm. 256

${ }^{14}$ E Kosasih. (2014), Strategi dan Pembelajaran, Bandung: Yrama Widya, hlm. 145 
penyelenggaraan; - penyusunan tema; waktu; - segala sesuatu yang menggambarkan capaian atau hasil, artinya dapat diadakan penilaian dengan jelas. Pada pokoknya, instrumen-instrumen RPP yang digaris dalam Permendikbud ini sangat detail dan banyak. Hingga kemudian mengalami revisi kembali sebagaimana dimuat dalam SE Menteri Dikbud RI, yaitu : - Sasaran; - Aktivitas; Monitoring. Kaidah-kaidah lain penyusunan RPP sebagaimana dalam Permendikbud adalah disusun oleh guru dengan sistematis, yang menggambarkan bagaimana sebuah pembelajaran dilakukan. Dalam hal ini fasenya dimulai dari sebelum, pada saat pembelajaran berlangsung, serta wujud penilaian sebagai akhir dari aktivitas. Makna penyusunan dilakukan secara sistematis adalah menggambarkan secara detail, sehingga setiap kompetensi sebagaimana diamanatkan dalam silabus dapat tercapai. Perihal dicapai melalui apa hingga bagaimana ukuran tercapainya, yang demikian mesti terurai secara jelas dan detail. Bagi guru, rencana ini adalah peduman yang sekaligus menggambarkan sisi fleksibilitasnya dalam rangka mencapai kompetensi yang digaris dalam silabus. rencana dapat berbeda dan sekaligus berubah-ubah, bergantung pada kondisi kelas yaitu menggambarkan tingkat kematangan psikis siswa dan lainnya. Bisa jadi juga antar sekolah tidak sama, namun secara prinsip segala sesuatu yang dirancang dan nantinya dilaksanakan dalam aktivitas pembelajaran ini adalah benar-benar menunjang bagamaina tercapainya kompetensi dalam silabus yang penyusunannya dilakukan secara kolektif atau bahkan secara nasional. Hal ini memang telah sepatutnya demikian, karena pendidikan menengah tersebut mensyaratkan kompetensikompetensi peserta didik yang terukur secara nasional. Pembelajaran PPKn termasuk merupakan mata pelajaran yang linear dengan kebutuhan nasional, oleh karenanya segala sesuatu yang berkaitan dengan kompetensi memang harus dirumuskan atau digaris secara nasional. Dalam pelaksanaannya di setiap sekolah, guru yang memainkan peranan ini. Artinya bagaimana seorang guru dengan segala daya dan upayanya dituntut mampu mencetak peserta didik dengan standar kompetensi sesuai dengan yang digaris secara nasional, tingkat kemampuan peserta didik dan segala sesuatunya harus benar-benar dipertimbangkan oleh guru. Prinsipnya, rencana pembelajaran ini merupakan wujud idealisme guru. Dalam arti bahwa guru diberikan keleluasaan untuk mengelola kelas sesuai dengan kondisi murud-muridnya, bisa jadi satu sama lainnya setiap sekolah berbeda dalam hal rencana pembelajaran. Meskipun sama-sama mata pelajaran PPKn, bahkan meskipun dalam satu daerah. Belum tentu karakteristik siswa atau peserta didik sama, hal ini adalah bergantung dari pemetaan yang dilakukan oleh guru. Bahwa makna rencana tidak hanya meliputi aktivitas pra pembelajaran dilakukan, namun makna rencana tersebut meliputi kegiatan-kegiatan sebelum pembelajaran bahkan hingga selesainya pembelajaran dalam bentuk monitoring atau penilaian. Dalam hal penilaian bukan berarti guru menilai rencananya tepat atau tidak, melainkan guru mengevaluasi murid-murid apakah telah memenuhi standar kompetensi sesuai dengan yang dipersyaratkan. Oleh karena wujud idealisme guru, maka penyusunan rencana pembelajaran ini juga berlangsung sangat fleksibel. Tidak susah untuk dilakukan perubahan-perubahan, namun bukan berarti menggeser capaian pembelajaran. rencana pembelajaran tersebut adalah pedoman yang berbasis pada kondisi, ketika kondisi berubah maka guru juga dapat melakukan perubahan. Singkatnya guru berwenang menyusun segala suatu dalam rencana pembelajarn sesuai dengan kondisi siswa, termasuk ketika dalam perjalanannya mengalami perubahan kondisi maka guru juga 
berwenang untuk melakukan perubahan terhadap rencana.

Berkenaan dengan penyusunan rencana dalam mata pelajaran PPKn tingkat SMP, mendasarkan pada Permendikbud tersebut maka yang perlu ditelusuri adalah KD. Berturut-turut KD kelas VIII - IX yang memiliki relasi dengan kesadaran hukum khususnya terkait dengan pandemi Covid - 19 adalah: - nilai yang dibangun dalam merumuskan Pancasila; - berperilaku sesuai dengan norma dalam masyarakat; pembahasan mengenai norma; - pembahasan mengenai kedudukan dasar negara; pembahasan mengenai peran lembaga negara; - legal order; - pembahasan mengenai hukum; - pembahasan mengenai kedudukan hukum dalam masyarakat. Melihat KD yang demikian, maka terlihat kebutuhan berkenaan dengan kesadaran hukum masa pandemi dituangkan dalam RPP mata pelajaran PPKn tingkat SMP sederajat. Dalam kompetensi mengenai nilai yang dibangun dalam merumuskan Pancasila, dapat direncanakan materi menyangkut bagaimana masyarakat Indonesia sebelum adanya Pancasila adalah masyarakat yang tertib. Menghargai satu sama lain, hingga berkeadilan sosial. Nilai tersebut yang diangkat dalam Pancasila, dan sesungguhnya esensi hukum adalah mengorganisasikan ketertiban ini. Bagaimana satu sama lain tidak saling menyakiti, hingga bagaimana keadilan sosial terwujud. Dengan adanya gambaran kondisi masyarakat Indonesia, maka akan menumbuhkan semangat kebangsaan yang tinggi dan tentunya tertib dan adil pada prinsipnya. Sementara dalam kompetensi perihal berperilaku sesuai dengan norma dalam masyarakat, rencana yang dapat digagas adalah seputar materi norma-norma yang dikenal dan diakui dalam masyarakat. Dimana hukum sebagai salah satu norma, yang kedudukannya beriringan dengan normanorma yang lain. Saling melengkapi, sehingga pada akhirnya akan tercipta ketertiban sebagai kondisi yang diidealkan. Dalam level sikap, maka setiap norma ini memiliki akibat jika tidak ditaati. Sehingga terjamin bahwa masyarakat akan berperilaku dengan mengikuti atau berdasar pada norma-norma yang hidup, tidak terkecuali adalah norma hukum. Lebih spesifik lagi kompetensi pembahasan mengenai norma, mudahnya berisi rencana mengenai perbandingan antara norma hukum dengan norma agama kemudian kesusilaan dan kesopanan. Dari pola perbandingan ini tergambar bahwa, disatu sisi norma hukum bisa timbul dengan substansi yang sama dengan norma lainnya namun adakalanya juga norma hukum tampil beda. Ukuran perbedaannya adalah terletak pada sanksi, yaitu sebagai sarana agar siapapun juga subyek akan taat terhadap apa yang digaris oleh hukum. Dalam konteks ini yang tidak kalah penting juga secara kritis mesti ditampilkan mengenai alasan norma tersebut ada, sehingga perilaku taat terhadap norma tidak sematamata takut akan sanksi atau akibat-akibat yang lain. Namun secara sadar benar-benar dikarenakan memahami bahwa taat adalah suatu kebutuhan, adanya norma tersebut adalah mendorong kondisi yang ideal. Siapapun juga yang ingin ideal dalam hidup dan kehidupannya, akan taat terhadap setiap norma yang berlaku di masyarakat. Sedangkan pembahasan mengenai kedudukan dasar negara, maka dapat dirancang mengenai konsekwensi kedudukan Pancasila dalam tertib hukum nasional. Dimana Pacasila tersebut sebagai sumber dari segala pembentukan hukum yang berlaku di Indonesia, seluruhnya adalah bersesuaian dan tidak diperkenankan bertentangan dengan Pancasila. Sementara pembahasan mengenai peran lembaga negara, sesungguhnya berkait dengan kewenangan-kewenangan baik yang tampil dalam konstitusi maupu wujud lainnya. Kemudian legal order menyangkut beragam peraturan perundangan, maka dapat direncanakan bentuk-bentuknya yang berkaitan dengan kondisi pandemi dan 
sekaligus secara kritis direfleksikan perihal alasan untuk taat terhadapnya. Hal ini pada akhirnya selaras dengan tema besar pembelajaran PPKn, yaitu membentuk karakterkarakter terutama menjadi warga negara yang baik. Bahwa siswa SMP sejatinya merupakan bagian dari warga negara, oleh karenanya diperlukan nilai kesadaran akan nilai-nilai yang mencerminkan sikap terhadap hukum. Dalam hal hukum merupakan bagian penting dalam kehidupan masyarakat yang dalam perkembangannya sesuai dengan kondisi akan mengalami perubahan-perubahan, maka penyusunan materi dalam rencana pembelajaran dalam rangka tercapai kompetensinya dapat dilakukan perubahan demi menyesuaiakn ketentuan hukum yang dinamis.

Sebuah rencana pembelajaran dalam perkembangannya yang berlaku sekarang berbentuk sangat sederhana, sehingga guru tidak terjebak dalam persoalan administrasi saja. Melainkan lebih dari itu guru PPKn sekolah menengah akan mampu lebih detail menangkap kebutuhan-kebutuhan atau kondisi peserta didiknya dan kemudian merancang design pembelajaran yang menarik. Meteri hukum sejatinya juga parktis dan aplikatif, artinya dapat langsung diterapkan dalam kehidupan sehari-hari. Berkenaan dengan kondisi pandemi yang sedang berlangsung sekarang, hukum sangat terlihat memainkan peranannya. Yaitu mengkonstruk masyarakat agar berlaku sesuai dengan kebutuhan ideal, bukan berarti menutup diri akan kritik melainkan menelusuri sejauh mana kebutuhan ideal tersebut benar-benar memang sudah teruji. Bahwa hukum sebagai sebuah rangkaian peraturan-peraturan, pada hakekatnya merupakan suatu nilai yang ideal. Prinsip yang digaris dalam rencana pembelajaran adalah menjadikan nilai-nilai tersebut tersemai dalam diri setiap siswa, sehingga kompetensi memahami norma dan lainnya yang berkenaan dengan hukum pada mata pelajaran PPKn di SMP akan dapat tercapai dengan baik. Bahwa guru sebagai pendidik yang memahami karakter serta kondisi siswanya, tentu dituntut mampu berkreasi dalam penyusunan rencana menyangkut pembelajaran. Dalam arti benarbenar aplikatif sesuai dengan karakter hukum, terutama dalam kondisi pandemi yang serba cepat terjadinya perubahan. Berkenaan dengan kebijakan, secara faktual yang dijadikan pedoman dalam perilaku masa pandemi adalah Instruksi Presiden. Maka fungsi guru yang dijabarkan dalam rencana pembelajarannya menyebut mengenai sumber kewenangan penyusunannya, kemudian sasaran dalam instruksi tersebut. Dalam arti hal ini adalah berkait dengan prinsip konkuren antara pusat dengan daerah, bahwa pelaksanaan instruksi tersebut pada akhirnya sangat bergantung pada setiap daerah-daerah karena memang telah terjadi penyerahan atau pembagian kewenangan urusan kesehatan. Namun demikian dalam bingkai negara kesatuan, penyerahan atau pembagian kewenangan ini tidak lantas melepas setiap daerah berkompetisi untukmelaksanakan instruksi. Namun peran pusat juga tetap tergambar, baik dalam bentuk monitoring serta segala sesuatu yang bersifat harmonisasi antar daerah. Hal ini sehingga siswa akan paham, perihal alasan lahirnya instruksi tersebut yang mendasarkan pada peraturan perundang-undangan hingga bagaimana pelaksanaan dari instruksi tersebut. Dalam instruksi tidak dijabarkan perihal sanksi, hal ini sekaligus menjawab bahwa unsur yang esensial dari hukum bukanlah sanksi semata. Siswa mesti sadar mengenai kegunaan hukum, tidak semata-mata takut akan sanksinya. Banyak hal yang dapat dibangun oleh guru melalui rencana pembelajarannya, termasuk dalam rangka membangun karakter siswa yang sejalan dengan kebutuhan negara khususnya pada masa bencana ini kreasi-kresi guru dalam rencana pembelajarannya akan sangat berperan. Jika itu benar-benar dilaksanakan dengan baik, maka sesungguhnya pembelajaran PPKn 
khususnya tingkat SMP tidak hanya dengan menghafal saja. Namun dapat menanamkan karakter sesuai dengan nilai-nilai yang ideal, siswa tidak hanya tahu tetapi sekaligus memahami dan berprilaku yang sesuai dengan nilai. Kebutuhan praktisnya memang masa bencana, tetapi dalam perkembangannya nanti sesuai dengan kondisi atau yang dibutuhkan oleh negara maka guru memiliki kewenangan untuk melakukan perubahan-perubahan atas rencana dalam pembelajaran. Siswa dalam hal ini akan benar-benar menjadi bagian dari warga negara yang mengetahui, sekaligus peduli terhadap kebutuhan bangsa dan negara. Guru adalah aktor yang berperan untuk itu, karena pengelolaan pembelajaran dan segala sesuatu dalam rangka tercapainya komptensi sesuai silabus adalah kewenangan yang dimiliki oleh guru. Maka tentu bagi guru terlebih dahulu juga senantiasa harus mampu menangkap permasalahan-permasalahan bangsa dan negara, hingga termasuk perkembangan hukum yang sangat dinamis. Tidak hanya secara tekstual dalam mengajarkan, namun lebih dari itu adalah kontekstual. Dalam arti mampu memahami dan bersikap yang sesuai dengan peranan terhadap tanah airnya, hal ini merupakan esensi dari pembelajaran PPKn.

Sejalan dengan kesadaran terhadap hukum pada kondisi bencana ini, pada akhirnya siswa tingkat SMP melalui pembelajaran PPKn akan dapat merefleksikan dengan presisi perihal macam aturan yang terkualifikasi sebagai hukum. Siswa SMP sejalan dengan kompetensi, tentu tidak sekedar paham cara menggunakan masker yang benar sebagaimana disebutkan dalam media-media. namun lebih dari itu, bahwa dengan materi yang berkenaan kesadaran terhadap hukum maka akan mampu secara kritis baik memahami, terampil, hingga bersikap atas segala sesuatu kebijakan yang dilakukan oleh pemerintah sebagai representasi dari negara. Siswa juga tidak sekedar diwacanakan bahwa tidak bermasker akan dikenakan sanksi, lebih dari itu ukuran sadar adalah mencerminkan nilai yang ada dalam dirinya perihal suatu aturan. Dalam arti memahami dengan benar mengenai berguna atau tidak, tepat atau tidaknya suatu aturan. Demikian juga berkaitan dengan kebijakan, bahwa kebijakan juga merupakan hukum dan salah satu sumbernya yaitu kewenangan berlandaskan peraturan adalah hukum. Sehingga akan dapat bersikap dengan tepat perihal mengapa kebijakan-kebijakan tersebut dilakukan, sesuai atau tidak dengan peranannya baik sebagai pusat maupun daerah. Bila ini sudah dimiliki, maka dalam diri setiap siswa tidak semata berpandangan hukum itu kejam karena di dalamnya terdapat sanksi. Namun dibalik itu secara kritis mampu merefleksikan bahwa hukum tersebut berguna dan karenanya patut untuk ditaati secara sukarela. Bukan tanpa alasan hal itu dilakukan, mengingat siswa SMP sebagai bagian dari warga negara adalah sebagai subyek yang terkait dengan pranatapranata yang memiliki unsur yuridis. Diluar itu keberadaaan siswa SMP dalam komunitas atau lingkungannya di masyarakat, akan dapat menyampaikan pandangan kritis perihal hukum ini kepada sesamanya. Sehingga berkenaan dengan fungsi kontrol, dimana pemerintah sebagai aktor yang memimpin pengendalian wabah bencana ini dapat sinergi atau didukung dengan baik oleh setiap lapisan masyarakat. Ketika rencana dalam pembelajara tersebut terwujud, kompetensi sebagaimana dalam silabus akan dapat tercapai dengan wawasan ilmu pengetahuan yang lebih kaya. Tidak semata-mata dengan menghafal ketentuan pasal per pasal dari suatu peraturan perundangan, namun memahami makna dibalik dibentuknya sebuah peraturan perundangan termasuk juga hukum pada umumnya. Ketika ini terwujud, maka jargon perang melawan covid tidak hanya retorika namun berwujud praksis. Dalam bentuk pola pikir, serta perilaku sehari-hari. Dimulai dari siswa SMP, berlanjut menyasar 
masyarakat pada umumnya. Tidak hanya taat, tetapi memahami alasan mengapa harus ditaati.

\section{Simpulan}

Simpulan yang diperoleh berdasarkan hasil pembahasan adalah kesadaran hukum pada masa pandemi Covid-19 pada pokoknya berkenaan dengan nilai dalam diri masyarakat atas setiap kebijakan terikat baik tingkat pusat maupun tingkat daerah bersesuaian dengan peraturan perundangan, konkritnya masyarakat tidak semata-mata taat namun benar-benar memahami maksud dan tujuan dari hukum. Di samping itu, sejalan dengan kewenangan guru PPKn SMP maka dapat disusun Rencana Pelaksanaan Pembelajaran (RPP) dengan substansi kesadaran hukum. Sehingga siswa SMP sebagai bagian dari warga negara akan tumbuh menjadi tunas atau potensi yang benar-benar sejalan dengan kebutuhan masyarakat, bangsa, dan negara.

Saran yang terkait dengan penelitian, bahwa RPP merupakan perangkat yang sangat penting dalam pembelajaran PPKn SMP dalam rangka mencetak lulusan yang bermanfaat khususnya pada masa pandemi Covid-19 ini. Agar peran tersebut dapat terwujud secara merata pada setiap sekolah, maka dibutuhkan semacam membangun kesamaan persepsi bagi setiap guru PPKn SMP dalam menyusun RPP.

\section{DAFTAR PUSTAKA}

\section{Buku}

Ali. Achmad dan Wiwie Heryani, 2012, Menjelajahi kajian Empiris Terhadap Hukum, Kencana, Jakarta

Ali. Achmad, 2002, Keterpurukan Hukum di Indonesia, Ghalia Indonesia, Jakarta

Kosasih. E., 2014, Strategi dan Pembelajaran, Yrama Widya, Bandung
Gde I. Pantja Astawa, 2008, Dinamika Hukum dan Ilmu Perundang-undangan di Indonesia, Alumni, Bandung

Muchsan, 1981, Beberapa Catatan tentang Hukum Administrasi Negara dan Peradilan Admnistrasi di Indonesia, Liberty, Yogyakarta , 2007, Sistem Pengawasan Terhadap Perbuatan Aparat Pemerintah dan Peradilan Tata Usaha Negara di Indonesia, Liberty, Yogyakarta

Hadjon. Philipus M., dkk., 2019, Pengantar Hukum Administrasi Indonesia, UGM Press, Yogyakarta

Soekanto. Soerjono, (2012), Faktor-faktor yang Mempengaruhi Penegakan Hukum, Raja Grafindo Persada, cet.11, Jakarta , 2002, Kesadaran Hukum dan Kepatuhan Hukum, Raja Grafindo Persada, Jakarta

Sudikno Mertokusumo, 2003, Bunga Rampai Ilmu Hukum, Liberty, Yogyakarta , 1999, Mengenal Hukum (Suatu Pengantar), Liberty, Yogyakarta

Suyon, 2015, Implementasi Belajar Dan Pembelajaran, PT. Remaja Rosdakarya, Bandung

\section{Artikel Jurnal}

Darmin Tuwu, Kebijakan Pemerintah dalam Penanganan Pandemi Covid-19, Journal Publicuho, Vol. 3, Number 2, May - July 2020 
A. Hamid S Attamimi, Materi Muatan Peraturan Perundang-undangan, Jurnal Hukum \& Pembangunan, Vol. 15,1985

\section{Peraturan Perundang-undangan}

Undang-undang RI Nomor 24 Tahun 2007 Tentang Penanggulangan Bencana (Lembaran Negara Republik Indonesia Tahun 2007 Nomor 144, Tambahan Lembaran Negara Republik Indonesia Nomor 2684) 